cultural and religious affiliation. In view of this, the intellectual heritage of the philosopher is of a great importance for explaining the process of Ukrainian ethno-building, but it cannot be used uncritically for the development of national strategies.

Key words: Orthodox Church, people, ethnic building, nation building, language, objective signs, mentality, cultural identity, religious practice, stereotyped behavior.

Одержано редакиією $\quad 15.02 .2019$

Прийнято до публікаиії 22.05.2019

УДК 1.051:141.2(045)

DOI:10.31651/2076-5894-2019-1-35-40
HONCHARENKO Valeria Anatoliivna,

Post-graduate student of the Department of Philosophy and Religious Studies, Bohdan Khmelnytsky National University of Cherkasy, e-mail: qj14918@gmail.com

\title{
THE CONCEPT OF THE WORLD PICTURE IN LATE WRITINGS OF LUDWIG WITTGENSTEIN AND MARTIN HEIDEGGER
}

\begin{abstract}
Summary. Introduction. The article tackles the concept of the world picture in the late period of philosophizing of Ludwig Wittgenstein and Martin Heidegger. Interest in the following topic is determined by the search for the conceptual ground for contemporary sciences and the affirmation of the world picture as not just a way of representation of the facts of reality but a semantic sphere of meaning, sense-making that unifies representational and relational aspects of reality. It should be noted that the comparison of Wittgenstein's and Heidegger's views on the world picture can be valuable for a profound understanding of possible fundamentals of our knowledge. Researchers are still puzzled on how to systematize interdisciplinary knowledge, moreover, how to achieve the unity of representation of what we define as reality.

Purpose. The purpose of the article is to define major similarities and principal distinctions of interpretations of both thinkers regarding the concept of the world picture, to analyze the primordial approaches to the following conception, to emphasize the meaning of the world picture for the cognitive inquiry and its role in framing the system of knowledge.

Methods. To achieve the aim mentioned above we apply the methods of comparative analysis, methods of the hermeneutic reinterpretation, analytical method and textual analysis of sources.

Results. After analyzing the texts, it can be stated that the world picture can be a link between meaning and knowing. The world picture can serve as a substantial foundation for conducting scientific research and unfolds the meta-level of the theoretic reasoning.

Originality. The originality consists in the attempt to comprehensively analyze the under-researched conception that can be fruitful in contemporary epistemological studies and interdisciplinary sciences.

Conclusion. It is necessary to mention that the conception of the world picture is crucial for the development of contemporary sciences whose aim is to produce approaches that make scientific research a human-dimensional one. The world picture appears to be a shared conceptual basis that encompasses not only metaphysics behind every language theory but covers meta-level of the whole that enriches analytical and phenomenological methods at large.
\end{abstract}

Key words: the world picture, Ludwig Wittgenstein, Martin Heidegger, representation, language, knowledge, reality.

Formulation of the problem. Interest in the problem is determined by the actualization in the search of epistemological foundations of knowledge and how epistemological cognitive forms can relate to the concept of scientific rationality. The concept of the world picture can be heuristic in epistemological and linguistic inquiry as a precondition that determines the semiotic field of sense-making and further knowledge systematization. The world picture is essential for creating a 
complex system of knowledge regardless of its conceptual complexity.

Analysis of the recent research and publications. Among the well-known and latest publications devoted to the Martin Heidegger's and Ludwig Wittgenstein's philosophizing we should mention next works: "The fourfold. Reading the late Heidegger" by Andrew Mitchell, "The early Heidegger's philosophy of life" by Scott Campbell, "Representation and reality in Wittgenstein's Tractatus" by Jose Zalabardo, "Wittgenstein" by G. H. von Wright, "Philosophy of Existentialism" by Otto Bolnow, "Ludwig Wittgenstein: The Duty of Genius" by Ray Monk, "Ludwig Wittgenstein: A Memoir" by Norman Malcolm, "Wittgenstein on Rules and Private Language" by Saul Kripke, "The New Wittgenstein" by Alice Crary, "An introduction to Wittgenstein's Tractatus" by G.E. Anscombe, "Beyond The Tractatus Wars: The New Wittgenstein Debate" edited by Rupert Read and Matthew A. Lavery, "The Oxford Handbook of Wittgenstein" edited by Oskari Kuusela and Marie McGinn, "Wittgenstein's Ladder: Poetic Language and the Strangeness of the Ordinary" by Marjorie Perloff, "Wittgenstein's Place in Twentieth-Century Analytic Philosophy" by P. M. S. Hacker, "Wittgenstein: Rules, Grammar and Necessity" by Gordon P. Baker, "Wittgenstein: Meaning and Mind" by P. M. S. Hacker, "The Pursuit of an Authentic Philosophy: Wittgenstein, Heidegger, and the Everyday" by David Egan, "Reading Wittgenstein with Anscombe, Going On to Ethics" by Cora Diamond, "Wittgenstein and Heidegger (Routledge Studies in Twentieth-Century Philosophy) by David Egan, "Groundless Grounds: A Study of Wittgenstein and Heidegger (The MIT Press)" by Lee Braver, "Transcendental Heidegger" by Steven Crowell and Jeff Malpas, "On Being in the World (Routledge Revivals): Wittgenstein and Heidegger on Seeing Aspects" by Stephen Mulhall, "A Companion to Heidegger" by Hubert L. Dreyfus, Mark A. Wrathall, "Being-in-the-World: A Commentary on Heidegger's Being in Time" by Hubert L. Dreyfus, "Heidegger, Philosophy, and Politics: The Heidelberg Conference" by Jacques Derrida, Hans-Georg Gadamer, Philippe Lacoue-Labarthe, Mireille Calle-Gruber, Jean-Luc Nancy, Jeff Fort, "The Banality of Heidegger" by Jean-Luc Nancy, "Heidegger: His Life and His Philosophy (Insurrections: Critical Studies in Religion, Politics, and Culture)" by Alain Badiou and Barbara Cassin, "Heidegger Explained: From Phenomenon to Thing (Ideas Explained)" by Graham Harman, "Not Saved: Essays After Heidegger" by Peter Sloterdijk, "Unframing Martin Heidegger's Understanding of Technology: On the Essential Connection between Technology, Art, and History" by Søren Riis and many others.

Purpose. The major task of our article is to analyze the concept of the world picture in Ludwig Wittgenstein and Martin Heidegger's philosophy, to compare their interpretations and to stress the distinctions, to evaluate the meaning of the world picture to the contemporary sciences.

Presenting the main material. The concept of the world picture can be heuristic in regards to epistemological fundamentals of knowledge, its generalization, correlation of language and knowledge. In Wittgenstein's early philosophy the world picture was rooted in the structure of language that was supposed to equal the structure of reality. "The Tractatus imagines an attempt to think through at the most general level what a conception of sentences as logically interconnected representations of reality requires" [1, p. 89]. To illustrate how language represents reality, Wittgenstein came to the picture theory that could symbolically connect language and reality on the analytical ground. The world picture is the concept that enables us to grasp a fact of reality as it is, to see it as a whole. "Talking later about the overall point of the picture theory, Wittgenstein stressed the use of the picture as a paradigm, a model that was supposed to make clear the essential similarities between propositions, pictures, and any other representation" [2, p. 36]. A researcher David Stern outlines that Wittgenstein introduced three kinds of representational forms within picture theory in the Tractatus: conventional, pictorial and logical forms. "Conventional form" refers to the production of the artificial convention, pictorial one covers the aspects that are attributive in a specific usage. Accordingly, the logical form is the generalization of the notion of pictorial form because it must appear in any representation under any circumstances. "As Wittgenstein cryptically intimates, the picture theory transmutes the notion of a pictorial relation into a quite general simile for the relationship between any representation and what it represents" [2, p. 40]. It should be stressed that pictures represent reality by modeling it, and whether or not 
these pictures are true or false doesn't necessarily contradict reality.

Notably, that world picture is presented a way of representation and it is crucial to elucidate how it is possible within Wittgenstein's early picture theory. Cambridge researcher Jose Zalabardo outlines that there is no contradiction between pictures and facts of reality because pictures are actual combinations of objects in the world and facts themselves. "Pictures and propositions would not represent the world for a subject that grasps them. They, the pictures, would be the ultimate representers" [3, p. 105]. It should be mentioned that pictorial representation faces a number of challenges because it can represent only things that are pictorial in nature. It means that it reduces the sphere of thinkable. Even if all possible logical worlds eventually limit themselves to the human ability to stretch its own thinking, the language is still more complex than its pictorial representers. Wittgenstein postulates in Tractatus that we cannot think illogically, nonetheless, he realizes that language cannot be seized within the logically constructed structure which leaves many phenomena of expression outside the system. Thus, logical picture of things has to be primordial in regards to representation. It is important to point out that logical form cannot be dependent on the truth-value of a proposition because otherwise, any picture of the world would be impossible to obtain. By arguing that world needs to have a substance to make picturing possible, Jose Zalabardo outlines that "picturing requires grasping the form of the picturing fact, but if this grasp was an instance of picturing, it would require grasp of the form of the 'second-order' picturing fact" [3, p. 183]. If the world does not have a substance, we will fall into constant regress of secondary representations without an ability to form a basis for objective knowledge.

Late Wittgenstein was occupied with the conceptions of ordinary language, language-games, nature of certainty and ethical issues. Despite the abandonment of the picture theory and a rejection of the primary ideas of the Tractatus, he goes on exploring the notion of the world-picture and its substantial role in our daily practices in "On Certainty". The thinker correlates a world-picture to a myth indicating that it can be interpreted as a precondition our knowledge is grounded on. A researcher Michael Kober suggests next definition: "A world-picture is a view of things particular to a location, held by a particular group of individuals at a certain period of time; it does not need to be a sophisticated, philosophical, or scientific system aiming at being once and for all true. But the notion of a world-picture itself does not have any explanatory power, it rather labels a setting" [4, $p$. 451]. It should be mentioned that the process of verification happens inside a certain system or a world-picture that establishes itself as a conceptual ground. Hence, the world-picture can be explained as a framing concept that systematizes the knowledge, in addition, it becomes a realm where totally different world-pictures can coexist even if they oppose each other fundamentally.

It is should be emphasized that the concept of the world-picture can be correlated with E. Husserl's Lebenswelt because Husserlian concept is defined as a sphere of pre-scientific certainties that determines forms of consciousness which expands the limits of the phenomenological method. It is reasonable to assume that Wittgenstein's world-picture can be interpreted as a semiotic field of sense-making beyond the worldviews that are shaped within language-games. Philosopher states that propositions find its sense in constant usage through language-game changing. "It is true that we can compare a picture that is firmly footed in us to a superstition; but it is equally true that we always eventually have to reach some firm ground, either a picture or something else, so that a picture which is at the root of all our thinking is to be respected and not treated as a superstition" [5, p. 83e]. The world-picture frames the primary ground for any worldview formations that lies at the heart of linguistic and cultural foundations. Thereby the world-picture can be represented as a conceptual basis that expands the boundaries of the analytical method as well.

Martin Heidegger's late philosophy examines the phenomenon of technology, poetry and its relation to the Being, the notion of humanism and the conception of fourfold. In the essay "The age of the world picture" Heidegger considers different connotations to approach the concept of the world picture reasoning that world picture matters when it stands before us as a representation that also relates to us. "Hence world picture, when understood essentially, does not mean a picture of the world but the world conceived and grasped as picture" [6, p. 129]. The world picture grasps all 
relational and representational aspects as one and becomes an articulation of the entirety. The thinker emphasizes that world picture can be only in a certain way which shows that it cannot be modified, thus, the world is the one presupposed for the change and becomes the picture anew. Therefore, "to be new is peculiar to the world that has become picture" [6, p. 132]. The world picture is integral for interpreting and understanding the uniqueness of historical age that is being hermeneutically reconstructed.

It should be stressed that Heidegger connects the acts of becoming of the world as a picture with the transformation of the man into a subiectum. From Heidegger's view, a man as a subiectum is not an inactive contemplator of the world but as a thinking-representing being. Following the Kant's idea of a man as an active subject that constructs the world, Heidegger considers that the human being as a carrier of action and rationality meditates on its own existence that articulates itself in hermeneutic self-interpretation within Being-in-the-world. "The word "picture" [Bild] now means the structured image [Gebild] that is the creature of man's producing which represents and sets before. In such producing, man contends for the position in which he can be that particular being who gives the measure and draws up the guidelines for everything that is" [6, p. 134]. The following cogitation exemplifies that the term "Gebild" created by Heidegger implies that the world picture's essence is standing-together, it is a structured system of what is being represented [im Vorgestellten]. Philosopher claims that the world's becoming as a picture enables arise of the humanism as a standpoint as well. When human being realizes himself and his relation to the world, he becomes involved in the world-picture as someone who lives it out. "Humanity is never a subject over and against or above the world apart from the world; rather, the subject is always in the world, a part of the world, and, indeed, is constituted by relations in the world" [7, p. 74]. Humanism is an expression of the human position among the beings, it is a man's centered worldview within the world-picture where a person makes himself a starting point of generality. Consequently, a human being undertakes the responsibility to embark the pathway of questioning where he explores the realm of meanings represented by the world picture.

Interpreting the connotations of Being, Peter Sloterdijk considers that "being as the infinitive of "I am": that is, understood as an existential, means to dwell near, to be familiar with" [8, p. 258]. The world picture emerges within the Being where human being dwells and articulates himself as Dasein. The world picture intends to output the language and experience beyond their boundaries to consolidate it all as a coherent entity. "World-pictures express a natural and legitimate tendency to unify and integrate experience even as the conflicts inherent in life prevent the questionable closure of life in a complete totality or system, as they inevitably face their limits in the self-generated antinomies and aporias of life" [9, p. 27]. The thinker affirms that it is essential to integrate different sources of knowledge in the pursuit of Truth. That's why states of mood that explicate our thrownness in the world and culture can actually sustain and contribute to scientific research. "Heidegger's position, then, is that factors such as culture and mood are always operative in the background of scientific statements" [10, p. 126]. Overall, the world picture can mold a conceptual basis for scientific or existential knowledge and become an affirmation of the truthful pursuance to the understanding of Being.

Conclusion. Ultimately, it should be outlined that one of the major distinctions in approaching the concept of the world picture is its application in contemporary sciences. Philosophy of language presupposes the postulation of metaphysics no matter how radical analytical project may sound. The world picture lies at the heart of creation that is not limited to the metalanguage or the universal grammar but opens up the way to Sense. Understanding the world picture means experiencing it, furthermore, it anticipates not only subjectivity of language-games but also a meta-level of the entirety. As a result, the analytical method must begin from such a basis in order to access philosophy and procedure of description altogether. For both thinkers the world picture is a way of representation of reality however Wittgenstein's interpretation of the world picture does not grant it as rigorously truthful. On the other hand, Heidegger argues that the world picture possesses the quality of truth because it relates to authentic existence that is fundamental for the philosopher. In fact, early Wittgenstein rejected universalist logic and the concept of truth as 
correspondence but in his late writings, he returned to the world picture to redefine its purpose. Thinker indicates that every argument has an end and our experience cannot be a foundation for judgment, indeed, the world picture can provide the ground for our groundless belief because certainty cannot be doubted as long as it justifies itself in daily practice. Thus, the world picture is the logical construction that grounds our thinking and designates the sphere of meaning. Finally, the major task of the world picture is to achieve the common ground for the meta-level of inquiry in contemporary sciences despite the postmodern paradigm in order to keep up with the world and produce theories that lead to the sense and sense-making, not to the postmodern denial of center and its total destruction.

\section{References (in language original)}

1. Ricketts T. Pictures, Logic, and the Limits of Sense in Wittgenstein's Tractatus / Thomas Ricketts // The Cambridge companion to Wittgenstein / edited by Hans Sluga and David G. Stern. - Cambridge: Cambridge University Press, 2017. - P. 54-96.

2. Stern D. Wittgenstein on Mind and Language / David G. Stern. - Oxford: Oxford University Press, 1995. $226 \mathrm{p}$.

3. Zalabardo J. Representation and Reality in Wittgenstein's Tractatus / Jose L. Zalabardo. - Oxford: Oxford University Press, 2015. - 263 p.

4. Kober M. Certainties of a World Picture: The Epistemological Investigations of On Certainty / Michael Kober // The Cambridge companion to Wittgenstein / edited by Hans Sluga and David G. Stern. - Cambridge: Cambridge University Press, 2017. - P. 441-479.

5. Wittgenstein L. Culture and Value / Ludwig Wittgenstein. - Chicago, IL: University of Chicago Press, 1980. $195 \mathrm{p}$.

6. Heidegger M. The Age of the World Picture / Martin Heidegger // The Question Concerning Technology and Other Essays. - Garland Publishing, Inc, 1977. - P. 115-155.

7. DeLuca K. Thinking with Heidegger: Rethinking Environmental Theory and Practice / Kevin Michael DeLuca / Ethics \& the Environment. -2005. - Volume 10, \# 1. - P. 67-87.

8. Sloterdijk P. Not Saved: essays after Heidegger / Peter Sloterdijk. - Cambridge: Polity Press, 2017. - 288 p.

9. Nelson E. The World Picture and its Conflict in Dilthey and Heidegger / Eric S. Nelson / Humana. Mente Journal of Philosophical Studies. - 2011. - Vol. 18. - P. 19-38.

10. Polt R. Heidegger: An Introduction / Richard Polt. - New York: Cornell University Press, 1999. - 197 p.

\section{References}

1. Ricketts, T (2017). Pictures, Logic, and the Limits of Sense in Wittgenstein's Tractatus. Cambridge Companion to Wittgenstein, 54-96. Cambridge: Cambridge University Press.

2. Stern, D (1995). Wittgenstein on Mind and Language. Oxford University Press.

3. Zalabardo, J (2015). Representation and Reality in Wittgenstein's Tractatus. Oxford University Press.

4. Kober, M (2017). Certainties of a World Picture: The Epistemological Investigations of On Certainty. Cambridge Companion to Wittgenstein, 441-479. Cambridge: Cambridge University Press.

5. Wittgenstein, L (1980). Culture and Value. Chicago, IL: University of Chicago Press.

6. Heidegger, M (1977). The Age of the World Picture. The Question Concerning Technology and Other Essays, 115-155.

7. DeLuca, K (2005). Thinking with Heidegger: Rethinking Environmental Theory and Practice. Ethics \& the Environment, № 1, 67-87.

8. Sloterdijk, P (2017). Not Saved: essays after Heidegger. Cambridge: Polity Press.

9. Nelson, E (2011). The World Picture and its Conflict in Dilthey and Heidegger. Humana. Mente Journal of Philosophical Studies, Vol. 18, 19-38.

10. Polt, R (1999). Heidegger: An Introduction. New York: New York: Cornell University Press.

\section{ГОНЧАРЕНКО Валерія Анатоліївна,}

аспірантка кафедри філософії та релігієзнавства

Черкаського національного університету

імені Богдана Хмельницького,

e-mail: qj14918@gmail.com

\section{КОНЦЕПЦІЯ КАРТИНИ СВІТУ У ПІЗНІХ ПРАЦЯХ ЛЮДВІГА ВІТГЕНШТАЙНА}

\section{ТА МАРТІНА ГАЙДЕПЕРА}

Статтю присвячено розгляду концепщіі картини світу у пізній філософській творчості Людвіга Вітгенштайна та Мартіна Гайдеггера та експлікації релевантності даного концепту для корпусу сучасних наук. Проаналізовано та закцентовано увагу на смислогенеративному характері картини світу та ї̈ примордіальному значенні для репрезентаиії. Визначено найістотнімі 
характеристики, на яких фундується картина світу та ї принципове значення у філософських поглядах обох мисленників. Виявлено корелятивний зв'язок між концепцією картини світу пізнього Вітгенштайна та гуссерлівським поняттям життєсвіту (Lebenswelt). Наголошується, шуо картина світу виступає як кониептуальна передумова для фундаџії системи знання, є сферою утворення смислу та фундаментальною основою для мовних ігор. 3'ясовано відношення картини світу до концепції істини та їх принциипове розходження у філософії Вітгенштайна ци Гайдеггера. Відстоюється думка, щзо картина світу передбачає не лише суб'єктивність, але й метарівень изілого принагідно до філософії та дескрипиії, які загалом протистоять сучасній постмодерній парадигмі, щзо заперечуючи метафізику, ведуть не до смислу, а до його иілковитої деструкиї. Окреслено евристичність концепиії картини світу для сучасної сфери гуманітарного знання.

Ключові слова: картина світу, Людвіг Вітгенштайн, Мартін Гайделтер, репрезентація, мова, знання, реальність.

Одержано редакиією $\quad 03.05 .2019$

Прийнято до публікаиії 22.05.2019

УДК 101.1:316 + 351.746

DOI:10.31651/2076-5894-2019-1-40-47

\section{ДОНІй Наталія Євгеніївна,}

доктор філософських наук, професор кафедри економіки та соціальних дисциплін Академії Державної пенітенціарної служби України, e-mail: doniyne@ukr.net

\title{
БЕЗПЕКА СОЦІАЛЬНОГО ПРОСТОРУ: ІСТОРИКО-ФІЛОСОФСЬКА РЕФЛЕКСІЯ
}

\begin{abstract}
Продемонстровано, що презентачія авторського бачення феномену соиіальної девіталізаиії особистості та иляхи стримування його поширення, щзо були зроблені в декількох раніше оприлюднених публікаціях, практично завжди в якості фону спиралися на конщепти «суспільство ризику» (Ul. Beck), «кризовий» та «травматизований» (P. Sztompka) сочіальний простір і доходили висновку, щчо однією з основних причин його появи є брак відчуття безпеки існування у індивідів, життя яких припало на межу ХХ-ХХІ ст. Мета публікаџії полягає в аналізі сочіально-філософських поглядів європейських любомудрів минулого та з'ясуванні виділених ними умов, що мали б сформувати безпечний соиіальний простір. У публікаиї̈ практично вперше у вітчизняному науковому дискурсі представлено сочіальну безпеку за принципом «просторового звороту», який вже здійснили європейські та американські науковці, але який практично ігнорований українським науковим співтовариством. Вказано, щңо починаючи з Античності філософи замислювалися щьодо умов безпеки соиіального простору. Зазначено, що Платон вважав, щь безпека - ие попередження шкоди, Аристотель вказував, що безпека соиіального простору залежить від наявності в державі середнього класу, Т. Гоббс був однозначний в позииії, щьо безпека - ие збереження життя $і$ його полегшення, а Р. Оуен основою безпеки соиіального простору визнав турботу держави про громадян в плані забезпечення їх роботою, а при необхідності - створення умов для тих, чия професійна сфера не дає благополуччя існування.
\end{abstract}

Ключові слова: безпека, соичіальний простір, потреба, шкода, середній прошарок, держава, влада.

Постановка проблеми. Презентуючи авторське бачення феномену соціальної девіталізації особистості та шляхи стримування його поширення [Див.: 1], ми так чи інакше виходили на концепти «суспільство ризику» (Ul. Beck), «кризовий» та «травматизований» (Р. Sztompka) соціальний простір і доходили висновку, що однією з основних причин його появи $\epsilon$ брак відчуття безпеки існування у індивідів, життя яких припало на межу XX-XXI ст. I це при тому, що важливість такого відчуття найбільш переконливо довів американській дослідник А. Маслоу, розмістивши в запропонованій ним піраміді потреб безпеку другим елементом, після фізіологічного, і віднісши іiі задоволення як потреби до базових. Саме за 